TRANSATLANTIC DIALOGUE $\checkmark$

Selected American Correspondence of Edmund Gosse 
THIS PAGE INTENTIONALLY LEFT BLANK 


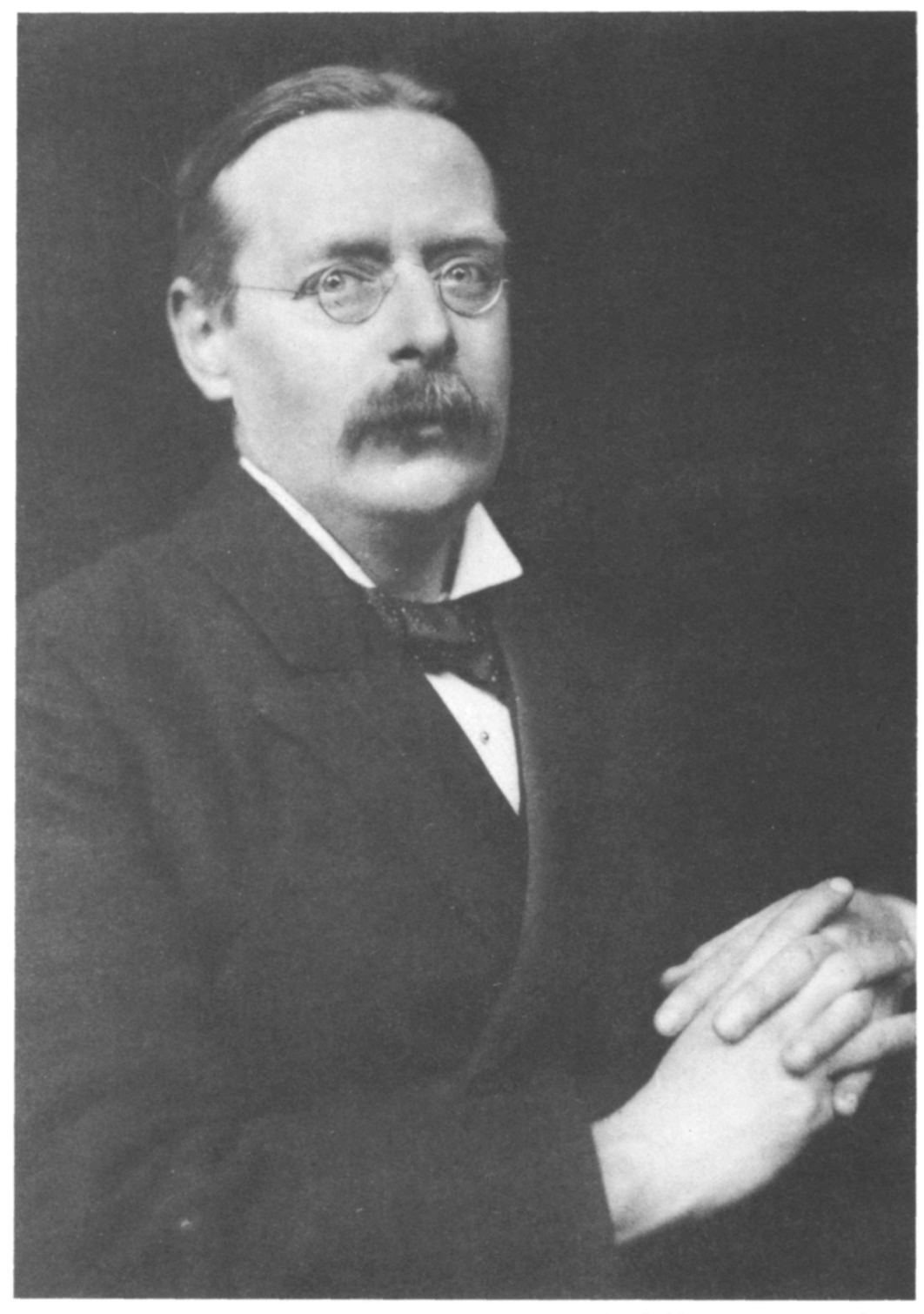

Cambridge University Library

Edmund William Gosse

March 1899 
THIS PAGE INTENTIONALLY LEFT BLANK 


\title{
TRANSATLANTIC DIALOGUE
}

Selected American Correspondence of Edmund Gosse

\author{
Edited, with an Introduction, by \\ PAUL F. MATTHEISEN \\ and \\ MICHAEL MILLGATE
}

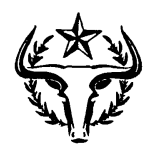

UNIVERSITY OF TEXAS PRESS, AUSTIN \& LONDON 
Library of Congress Catalog Card No. 65-16471

Copyright (C) 1965 by Paul F. Mattheisen and Michael Millgate All Rights Reserved

Published with the assistance of a grant from the Ford Foundation

under its program for the support of publications in the bumanities and social sciences

Printed in the United States of America by the Printing Division of The University of Texas, Austin Bound by Universal Bookbindery, Inc., San Antonio

Acknowledgments of permissions to reproduce copyrighted material begin on facing page. 